\title{
Mainstreaming Gender in Planning
}

Roohi Naeem ${ }^{*}$, Aisha khan

Urban planner, Lahore College for Women University Pakistan

DOI: $10.36348 /$ sjet.2020.v05i11.007 $\quad$ | Received: 04.11.2020 | Accepted: $13.11 .2020 \mid$ Published: 16.11 .2020

*Corresponding author: Roohi Naeem

\section{Abstract}

The continuous negligence of gendered and personified rights to daily life discloses the limits of the right to the city. Like other developing countries, absence of safety measures averts women from participating in various activities in the cities of Pakistan. Public transport, walking, and accessibility still disproportionally impact females. This research study points out the techniques of considering spaces that ultimately give attention to integrated spatial setting accommodating both genders. The paper also highlights the existing practices adopted by Government of Pakistan and recommends to plan and design safer public places for females with features that improve security of women of all age groups. The findings of the paper shall help the government departments and decision makers in spreading consciousness among the general public on the proposed and implemented action plans to develop a secure, safer and women-friendly city.

Keywords: Safety, practices, Government Departments, Women.

Copyright $\odot 2020$ The Author(s): This is an open-access article distributed under the terms of the Creative Commons Attribution 4.0 International License (CC BY-NC 4.0) which permits unrestricted use, distribution, and reproduction in any medium for non-commercial use provided the original author and source are credited.

\section{INTRODUCTION}

Predictably, towns have been designed and planned to facilitate the general needs of the residents. This deceptive objectivity did not consider gender variability in most of the aspects. Planning of the cities is generally stressed on masculine roles, which place the benefits of financial groups' primary to the broader problems, excluding the practices and securities of women as well as other marginalized groups. The fact that males and females experience various socialization procedures by which inadequate gender control relationships are structured has been completely ignored in urban planning as seen insubordination of females to male's will and their exclusion from the perception of the city as well as public life in general [1]. Therefore, gender neutrality, in fact, hides gender discrimination in relation to women's specific requirements and interests. Therefore, we need to strengthen and develop actions, processes, and public policies on gender equality in planning to build and improve the voices and experiences of cities especially women. These are women, who promote development and support life in the territories in which we live. Thus, the research will help to find out the laws that exist currently, the intensity of their implementation and how to make our cities inclusive in urban design and in social aspects by gathering the current scenarios. Inclusive and accessible public places are deigned on the philosophies of safety, walkability, the variety of choices, personalization and environment friendly for everyone [4]. Urban planners and architects, as creators of public places, must reflect the needs of both genders in the design and amenities of public places [5].

This paper precisely explains the major issues regarding gender in the country Pakistan. It says that the policy regarding planning is gender blind. It is obvious that gender and planning is greatly linked because gender has huge effect on the urban planning and as well as the design regarding living and working in a specific environment. The planning policies in Pakistan has totally ignored the greatest fact of doing inclusive planning for the women, thus it is obvious that the work and public place is differently utilized by the male and females.

The argument is this that the suburban and urban spaces always support the stereotypically the activities of the male people. So, by these methodologies regarding planning depicts this society as a male-dominant society [56]. Therefore, the differences in the gender have indication for all the elements of the spatial planning and as well as the built environment [8] ranging from the small scale of the houses interior design to the planning of the city at large scale. Moreover, it had been argued that women are the one who has to face various kind of issue and as well as the disadvantage by being in the built environment 
because it is not planned out by considering their needs [8].

\section{AIM OF THE RESEARCH}

The research aims to explore key challenges that females are facing in public places. This research has briefly illustrated the role, rules and regulations of planning authorities, agencies, architects, urban planners and consideration of women safety element in their design patterns, policies and plans. Planning responsive and inclusive public places for women necessitate urban planners and designers to introduce features of women safety, privacy and comfort in design and layout of public places.

\section{LITERATURE \\ Need for Safer Public Places}

This subsequent section of the research ought to address more clearly the issues that women generally face in the society and emphasizes some of the difficulties that result from ill consideration of women in planning. It is being known that gender has effective role in urban and regional planning and the patterns of design of public and urban places where people are living and working [6]. According to Greed and Reeves, Gender variances have suggestions and implications for all spatial planning aspects as well as design patterns of a built environment [7]. It has also been claimed that built-up areas and peripheral areas support typically dominant male activities [8]. Greed also argued that most frequently these are females who suffer and face challenges in the built urban environment that is being established with slightly following women's requirements. These issues have now been controlled to some extent in urban areas, but the issue still needs to be regulated.

Females experience different forms of ferocity, harassment and violence in public places that are aggressive staring, sneering, passing comments, stalking, gazing, leering and may also lead to sexual assault [4]. Several research studies in various cities throughout the world exhibited that nearly $60 \%$ of females stated that they feel insecure in urban places [56]. Fear of fierceness limits females accesses to public places that include employment, medical facilities, schooling, health, public toilets, teaching and recreational facilities $[8,2]$.

According to Blumberg, travel patterns of females are more intricate than males [9]. They travel more often for childcare purpose, institutes, workplaces, and shops in trips that are stated as 'trip-chains' [10]. Further Greed specified that comparing to males, number of females accountable for accompanying kids to school is twice bigger. Also $25 \%$ of automobile trips are commenced by females where only $30 \%$ of females feel convenient to use car through the daytime [9, 8]. Deprived transport system and absence of services like shopping, the location of workplace, deficiency of accommodations and inconvenience confine women's access to the labor markets too. Females did not feel secure when they travel alone in the dark, particularly in the inner areas and old areas of municipalities or social housing domains [11]. Irregular consideration of landuse zoning policies has a greater influence on women's mobility. Oxfam argued about hovering awareness and need to consider gender inclusivity in planning. He contends that development should take needs of women into account and focus on convenient transport routes that care for female travelling design patterns. Actions must be taken to make communal places harmless and secure at dark and day too and must focus on mixed-use development [29].

\section{What makes City's Public Places Insecure?}

In Canada, poll was carried out in the year 2000 which revealed that almost $60 \%$ of females are scared of moving alone in their zone at evening as compared to men $[11,12]$. Similarly, in Argentina a CISCSA report declared that $83 \%$ of the sufferers were women in cases against honor and harassment [13, 14]. Females sense that their surrounding places are threatening and ultimately, they avoid use of the public places that detect to be insecure [5]. Public places like roads, boulevards, highways, public squares, small neighborhood's streets or public parks, are frequently used by men more as compared to women. This contributes to the assumption that females are frightened, and they are repeatedly treated as feeble, deserted and vulnerable. This situation makes females, sufferers of fright and violence [16].

Few factors certainly make public places vulnerable for women:

- Deprived urban infrastructure, poorly lighted streets which make the entire environment dark especially in inner-city areas;

- Deprived parks and vacant lots, inadequate public spaces, poor signage, deficiency of public toilets specifically for women;

- Absence of suitable public transport, rush at junctions, terminals and bus stops;

- Nonexistence of representatives, security guards at roads and aggressive behavior of police also make women feel hesitant at public places;

- Thoughts, opinions and beliefs regarding proper behavior usually lead to unwillingness to complaint and protest against violence.

\section{Designing Reliable/Safe Public Places for Women a. Roads and streets}

It was stated in a book named as "The Death and Life of Great American Cities" by Jane Jacobs that cities are really not alike to suburbs as they have more population. Moreover, in this book she argued that the city is a larger place so it involves massive number of strangers. So, in order to make it a friendly place for all the citizens it is really essential to make roads and 
streets safe and sound. Therefore, this can be achieved by identification of the public places and by keeping an eye on the street and as well as on the road.

Continuous eyes on the street is extremely significant to mitigate the various kind of crimes and conflicts which results in maximum safety for the females as well. The highways and the roads should be easily accessible from the location. Additionally, the good kind of lightening at the public areas, maintained sight lines, clear way out, signboards, amenities for exercising, giving priority to pedestrians, eating and playing for various groups helps in enhancing the safety for the women as well. Thus, the public areas that are not sustainable, less maintained and lack the inclusive planning makes women insecure and uncomfortable.

\section{b. Transportation}

Women confront the extreme level of pestering, touchiness and irritation in public transport among all others public places [18, 6]. Public transport provides a venue for inappropriate conducts and actions during peak hour $[19,20]$. Women agitation in using public transport stimulates them to change their behavior and mode of transport [22]. In the interest of women safety and mobility, several transportation alternatives are presently functional in many cities all over the world. Literature form various international studies illuminate that females feel atrocious to use public transport, waiting for areas of bus terminals and walking through a street. It is internationally recognized that women's travel behavior, customs, practices, patterns and modes are not like men's. Whereas, legible, robust and responsive public spaces design represent the image of an inclusive city [25].

\section{c. Infrastructure}

The act of rapid urbanization and increasing percentage of basic requirements of the families made a necessity need of the women to work in Pakistan and leave their homes for livelihood. The Thynell asserted that the women who do jobs contribute their maximum time for working in the public areas mainly in the sector of transport and markets. There is a great advantage of inclusive transportation planning focusing on both female and male residents of the cities. Thus, this ensures the great quality of life. Moreover, the urban areas and the cities are the pivot of economic engine, ideas, and opportunities for both gender and modern civic amenities. But the urban planning in Pakistan still lacks the provision of inclusive planning for the women focusing on their needs.

The transport and road infrastructure has a massive influence on the safety of the women. The parking lots, well-lits and as well as the sidewalks are the main feature need to be focused for women's safety. Moreover, the crosswalks, accommodation of strollers in sidewalks, parking spaces specific to women carrying kids, clear signboards, sight lines, should be surely available for the women. Furthermore, the public areas such as platforms, stations, cab stations and the bus terminals, must be made safe for the women.

\section{d. Public Parks}

Sustainable urban parks and green spaces play strategic functions in an urban society [22]. Urban parks contribute as a natural habitat and place of serenity in a jungle of concrete structures and commotion of traffic. Urban parks provide noise and stress-free environment to urban dweller and enrich the urban environment with recreational facilities. People pursue public parks because they offer interaction with natural, social and cultural domains of life, which impart moments for gathering with friends, family and helps to form a comfortable and secure arena $[6,35]$. In the compendium of urban land uses, parks and open spaces are considered as places where all segments of society: male, females, elderly and children can entertain their lives [60].

\section{e. Public Squares}

The literature shows that inclusive and functional public places safeguard women from all kinds of aggression and harassment. Women feel unsafe in public places and avoid visiting public squares due to undesirable remarks, comments and staring [30]. Irrespective of the size of the squares and malls, safety is the foremost perimeter. If this perimeter is kept in mind, people perceive the safer environment and pleasing activity [18]. Safety for females can be improved by providing them with an optimal choice of routes to and from their areas. The range at which any public setting permits and gives them substitute options for movement on any area is stated to as having the physical permeability within that area [32]. Planners must ensure an active as well as visible edge to encourage and create this perimeter in any recreational zone. Women's accessibility to parks and public squares must be focused; females should be aware of all alternative routes, emergency exits, the safer entrance, exit pathways and special areas for families.

\section{f. Public toilets}

Women usually fears against the aggression and the antagonism mainly in the public places such as city squares, public streets and the parks. The organizations, selection of these civic areas and the urban planning of certain areas induce this fear. This kind of environment and lack of inclusive planning for women makes female less confident in living their lives which immensely has an impact on the utilization of public places such as bazars, public parks, public transit women mobility patterns.

However, the most essential thing which lacks in the Pakistan urban planning is the development of public toilets specific for the women in the various parts of the cities. Whereas, in other countries of the world there is inclusive planning in the cities by covering 
aspects of both males and females. Moreover, the sustainable towns of the world are perfect example of the inclusive planning. In Lahore city there are almost 12 public toilets which are operational and falls under the metropolitan corporation of Lahore. Further, 27 public toilets are located along the shahdra-Gujjumata Metro Bus route. So, as a conclusion there is inadequate provision of public toilets especially in the public areas which is the main problem that women don't feel safe to visit public places.

\section{LEGISLATIVE FRAMEWORK National and International Commitments for Women's Rights in Pakistan}

In December 1979, General Assembly of UN proposed the Agreement to eliminate discrimination against girls and women that was named as CEDAW [58]. It was put into force as the global treaty in September 1981; nearly 100 countries have settled to be destined by its rules and provisions. UN perceptions of gender-mainstreaming preamble state "equality of women and men constitute a fundamental right for all". Some of its fundamental principles that are in collaboration with research paper are as follows:

- Multiple discernment and disadvantage is crucial to ensure equality;

- An equal contribution of females and males in decision-making is prerequisite;
- Elimination of gender categorizes fundamental rights to achieving balance;

- Properly resourced strategies and programs are essential for attaining equality.

Pakistan became a participant of CEDAW on $6^{\text {th }}$ February 1996 and contributed in Beijing Conference [59]. It was mainly significant for the improvement and development of women in Pakistan. The main aim of it is to help and achieve equality for females within their societies. It indulges them to provide measures to eradicate discernment against women in all public spheres ranging from legitimate amendments, legal and managerial reforms, deviations in physical, social and economic strategies and policies and the education sector.

National report of Pakistan for habitat III of 2015 in its chapter 4 section 4.6 highlights the issues women and girls bear, a country having low literacy rate is because of not considering females in making planning decisions and designing. The draft proposed the policies and regulations in housing, infrastructural setup, laws for females such as Protection against Harassment of health and professional security at workplaces and right of complaint about violence and erotic harassment. Similarly, SDG's goal 5, 10, 11 also indicate to integrate women in planning.

Table-1: International Legislative era's and Pakistan's implication towards it

\begin{tabular}{|c|c|l|}
\hline Sr. No. & Era & NATIONAL AND INTERNATIONAL COMMITMENTS \\
\hline $\mathbf{1}$ & 1948 & Universal Declaration of Human Rights \\
\hline $\mathbf{2}$ & 1985 & Nairobi Forward-looking Strategies for the Advancement of Women \\
\hline $\mathbf{3}$ & 1995 & Beijing Declaration and Platform for Action \\
\hline $\mathbf{4}$ & 1996 & Convention on the Elimination of All Forms of Discrimination against Women \\
\hline $\mathbf{5}$ & 1998 & National Plan of Action for Women \\
\hline $\mathbf{6}$ & 2002 & National Policy on the Development and Empowerment of Women 2002 \\
\hline $\mathbf{7}$ & 2015 & National report of Pakistan for habitat III of 2015/ SDG's vision 2030 \\
\hline
\end{tabular}

The Government of Pakistan and particularly Government of Punjab has been sincerely engaged in legislation for introducing and implementing numerous substantial measures for the development of women in all dimensions of life and empowering women by combating gender discrimination, brutality and aggression against women. Steps were taken to stimulate female's participation and representation in existing democratic and public body's structures. 18th Amendment in constitutional act plays a vital role in this regard as it empowers provinces to formulate policies, laws and rules for women rights and grant funds to regions for women's empowerment.

Table-2: Statutory Provisions under the Constitutional Rights of Women in Pakistan

\begin{tabular}{|c|l|}
\hline Article (Section) & \multicolumn{1}{c|}{ Contents } \\
\hline $\mathbf{2 5 ( 1 )}$ & Constitution grants masses to enjoy equal rights before the law \\
\hline $\mathbf{2 5 ( 2 )}$ & Constitution outlaws gender discrimination \\
\hline $\mathbf{2 5 ( 3 )}$ & Authorize the state to make special laws and rules for problems faced by women and children \\
\hline $\mathbf{3 4}$ & Safeguards women right to contribute in all spheres of national life \\
\hline
\end{tabular}

Source: Punjab Women Development Guidelines

\section{National Legislative Structure}

A well thought out national level legal framework exists in the country for the protection and safety of women who comprise on the subsequent laws and amendments. 
Table-3: Laws and policies in Pakistan

- Prevention of Anti-Women Practices Act, 2011

- Criminal Law (Amendment) (Offense of Rape) Act 2016

- Criminal Law (Amendment) (Offences in the name or pretext of Honor) Act, 2016

- Prevention of Anti-Women Practices Act, 2011

- $\quad$ Prevention of Electronic Crimes Act, 2016

\section{Source: Punjab Women Development Guidelines}

The act named as Prevention of Anti Women Practices describes that there are various unbiased and as well as oppressive actions and practices in opposition to women. Similarly in the Criminal Law the amendments were conducted in the year 2016 which covers the crimes such as gang rape, rape, rape of minors and as well as the disabled people. Moreover, it conveys that criminals will be given the punishment of lifetime imprisonment and fine as well.

\section{Policy for Women Authorization in Punjab}

Table-4: Provincial policies

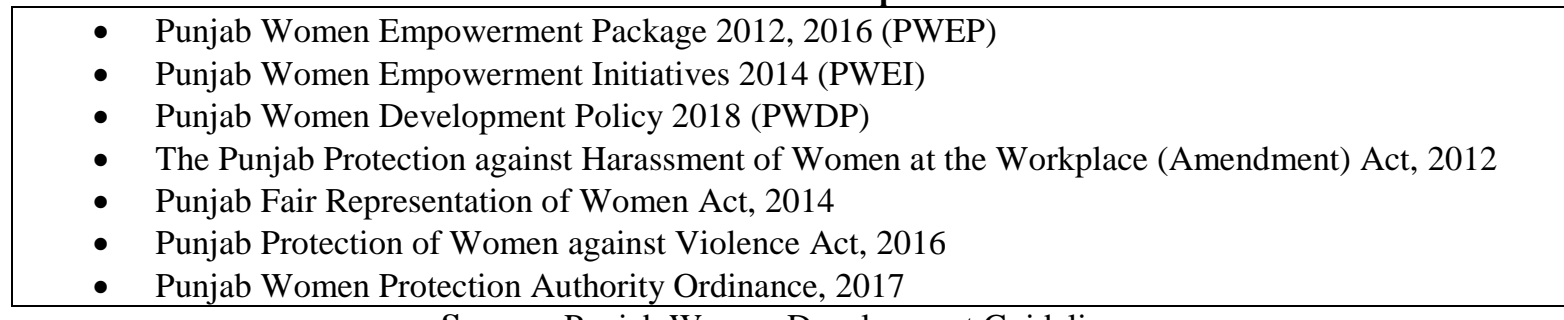

Source: Punjab Women Development Guidelines

\section{RESEARCH METHODS}

The work reported here involves both primary and secondary data collection. A comprehensive literature survey was carried out to collect the existing data on "laws for women" on Provincial and National level. The Exploratory Research emphasizes on the planning and designing of safe public places for females. The planning and design process is an essential facet of making safe cities for females. Observational survey was carried out by researcher to observe deficiencies in planning system and design patterns. Primary data was collected from women residing in Lahore City. Secondly, the secondary data was collected from different sources (planning agencies, government departments). SPSS and Microsoft Office were used to analyze the data.

\section{RESULTS}

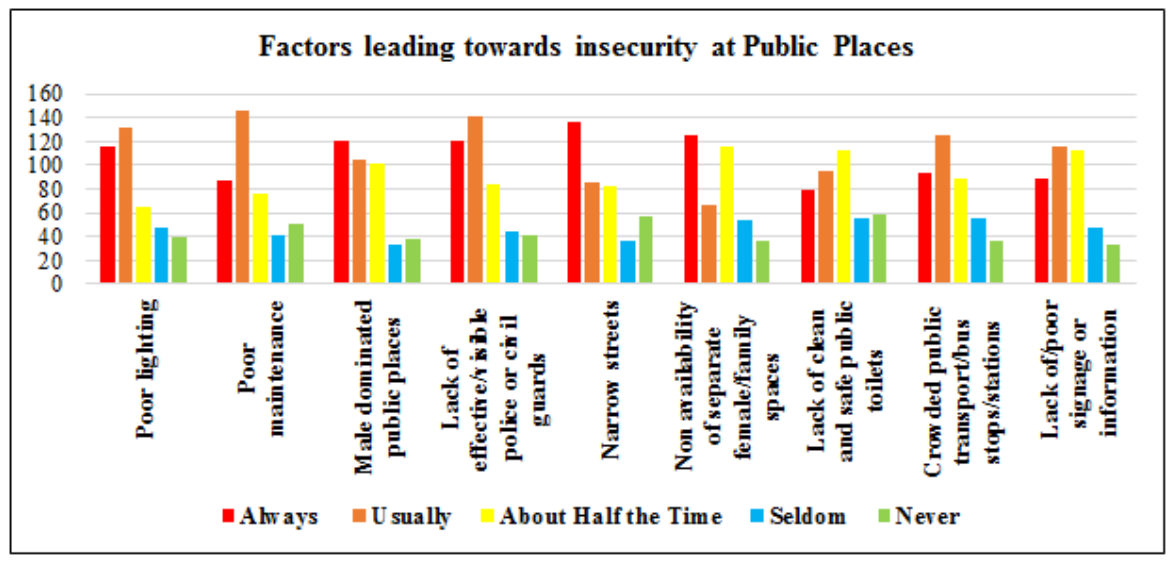

Fig-1: Factors leading towards insecurity at Pubic Places

Source: Researchers'2020

The result shows that narrow streets always contribute towards the insecurity of women at public places while poor maintenance, poor lighting and lack of effective/visible police or civil guards are the usual reason that leads to the insecurity. The research of [11] also stated that poor lighting and maintenance of public places threaten women to use that place. 


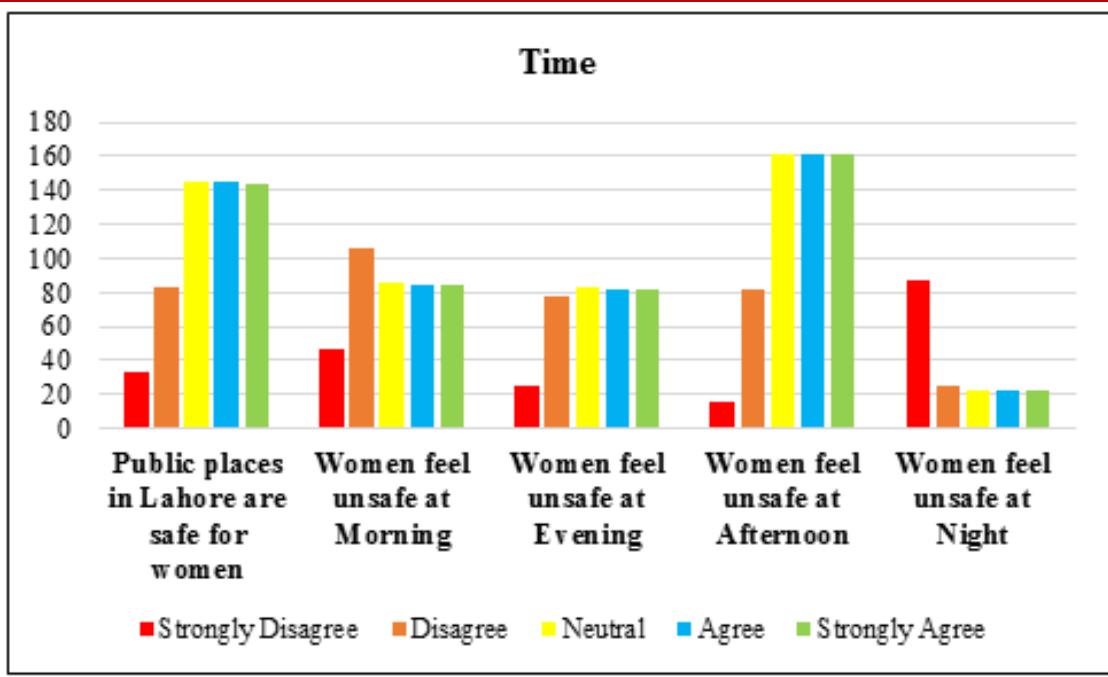

Fig-2

Source: Researchers'2020

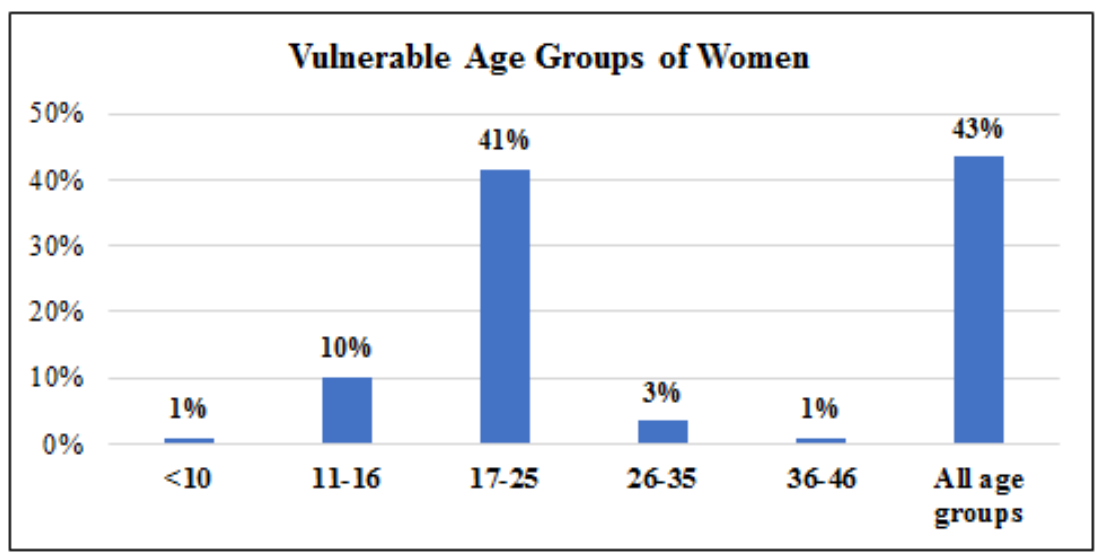

Fig-3: Age group

Source: Researchers'2020

The chart describes the public view point that young girls are most vulnerable as age group 17-25 and 11-16 have the highest percentages. According to the research [44] young girls are most vulnerable and they feel unsafe while going to school and discontinue their studies as their parents do not allow them to go because of harassment.

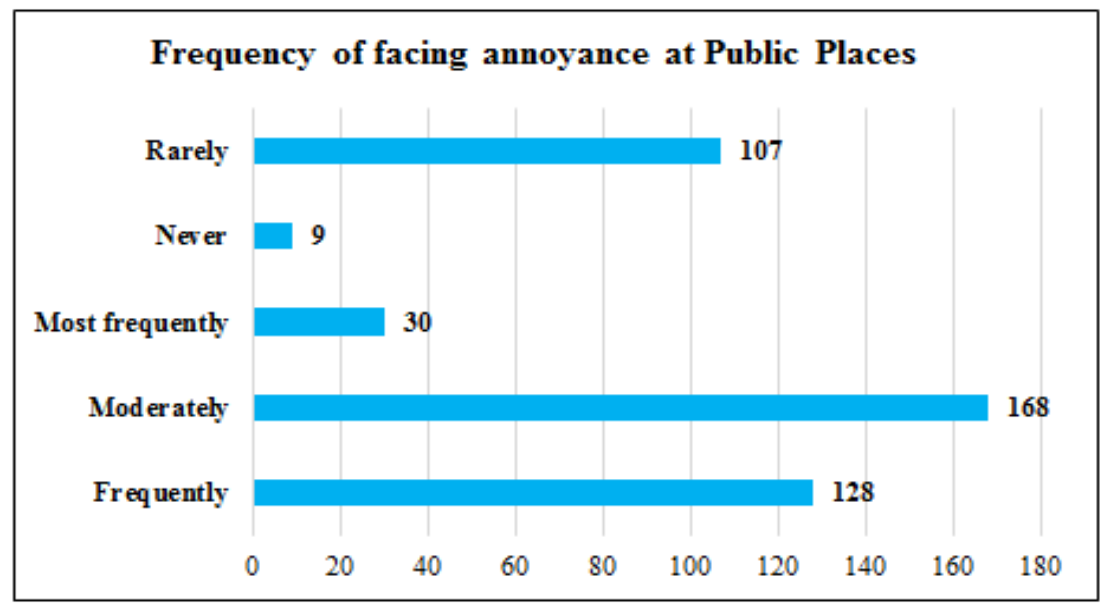

Fig-4: Annoyance at public places

Source: Researchers'2020 
Respondents were questioned about the annoyance at public places. Most of the respondents answered that they moderately feel annoyance, some of the respondents frequently face while some people rarely face it. So, there are different views from the respondents. According to study [44] most of the women face annoyance at public places.

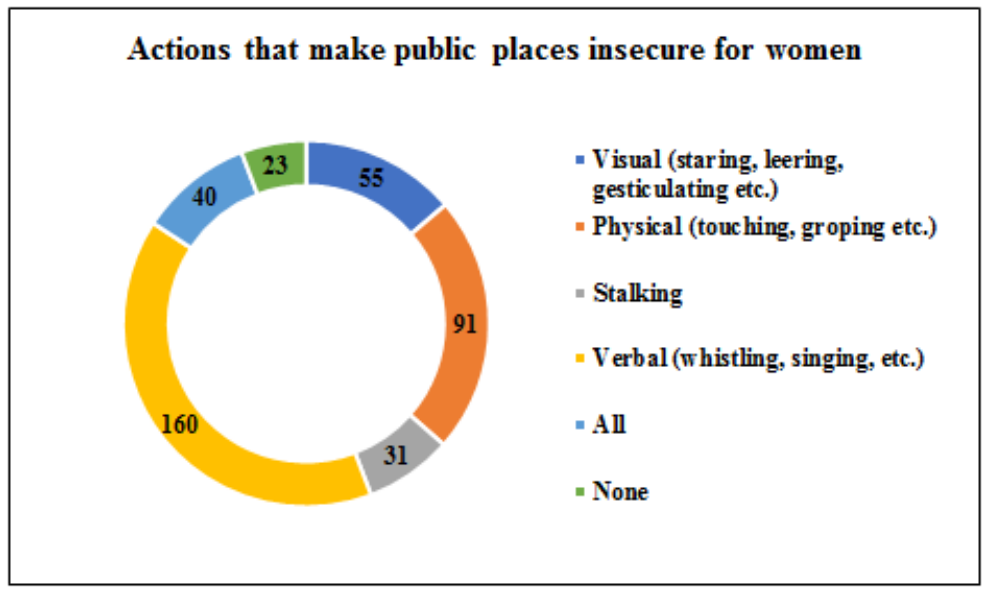

Fig-5: Actions that make public places insecure

Source: Researchers'2020

It was inquired from the respondents that what public actions makes them insecure. Majority of the people stated that verbal (whistling, singing etc.) actions makes them insecure. The second main action of insecurity is physical (touching, groping etc.). According to the study [44] most of the time they face verbal harassment and unethical words from men in public transport or on streets.

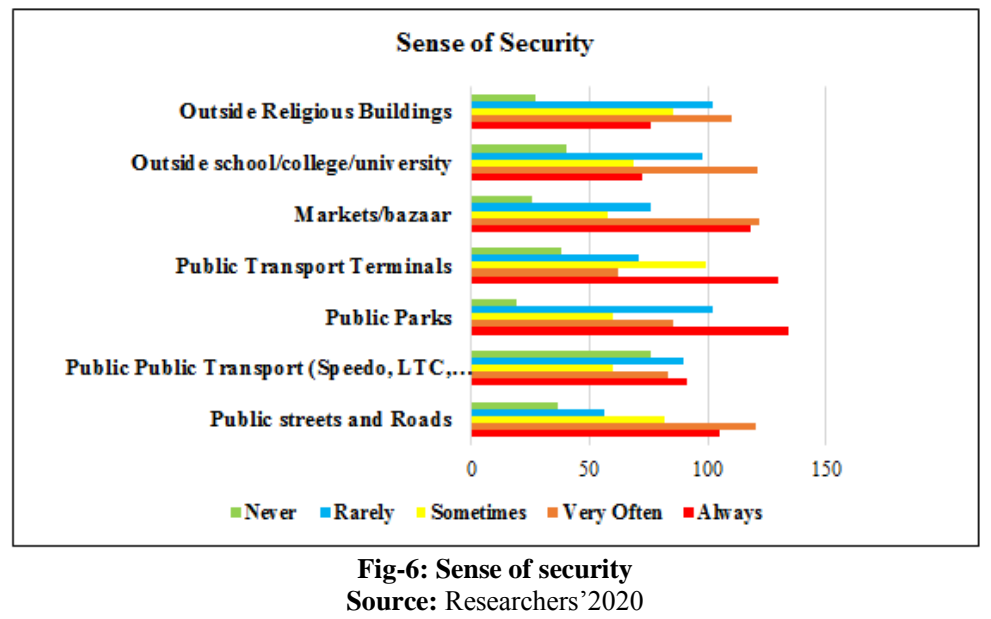

The results of the survey demonstrate that public parks and public transport terminals always have the sense of security while markets, schools/college /university and streets/roads mostly and low in public transport (Speedo, LTC, Rickshaw, Metro buses). According to the researcher [44] public parks are the safe place for women at day time where they can spend and enjoy with their children and unsafe in public transport.

\section{CONCLUSION}

Women are the integral part of the society. In the urbanized world the women are the central character. It is really significant for women to participate and represent themselves in various domains of governance, business and development. According to the changed role in society women are free to visit various important places such as workplaces and other public places. These all places usually turn out to be the hub of ferocity, discomfort and antagonism for the women. Therefore, the other places such as underpasses, pedestrian sidewalks, public restrooms, passageways, bus-stops etc. lacks the focus of inclusive planning for women.

However, in order to do inclusive planning for women who is safely designed and planned the various professionals should focus on the following parameters:

- Lightening

- Landscaping

- Visibility

- Motorized Traffic 
- Pedestrian Circulation

- $\quad$ Street Furniture

- Potential Hiding Spots

- Sign Boards

- Security Staffs

- Closeness To Other Public Places

- Contiguity To Emergency Services

- Easy Access To Public Transport

Thus, each of the these areas planning should be ensured by the means of inclusive safe planning respective to the females of all age who frequently utilize the public places. Similarly, one can also say that Planning and the built environment is only one aspect of a complex system that should ensure safety for women as a whole and there has been some limits to what planning can achieve. The other parts of the market system and our cities and most importantly policies and strategies processes that combine to produce inequalities also need to be readjusted to ensure more equal treatment of women or disadvantaged groups more generally. The reliance on legislation to progress gender inequalities is positive but must also be supported by broader changes in policies and practices to address gendered disadvantage. Planning and the built environment alone cannot redress fundamental inequalities.

\section{REFERENCES}

1. Randhawa, M.S. (1957). Flowering trees in India. In: B.m.: Icar.

2. Morsy, M. (2012). Safe city free of violence against women and girls is a safe city for everyone Egypt's experience. Égypte/Monde arabe, (9), 151164.

3. Un-Habitat. (2013). Planning and Design for Sustainable Urban Mobility: Global Report on Human Settlements; 2013. B. m.: Routledge, 2013.

4. Defining a Global Urban Development Agenda ScienceDirect [online]. [vid. 2018-08-04]. Dostupné

z: https://www.sciencedirect.com/science/article/pii /S0305750X15002508

5. United Nations Human Settlements Programme. (2009). Planning Sustainable Cities: Policy Directions: Global Report on Human Settlements 2009. UN-HABITAT.

6. Jalaladdini, S., \& Oktay, D. (2012). Urban public spaces and vitality: a socio-spatial analysis in the streets of Cypriot towns. Procedia-Social and Behavioral Sciences, 35, 664-674.

7. Fenster, T. (2005). The right to the gendered city: Different formations of belonging in everyday life. Journal of Gender Studies, 14(3), 217-231.

8. Greed, C. (1994). Women and planning: creating gendered realities. Taylor \& Francis.

9. Greed, C., \& Roberts, M. (2014). Introducing urban design: interventions and responses. Routledge.
10. Whitzman, C., Legacy, C., \& Andrew, C. (Eds.). (2013). Building inclusive cities: Women's safety and the right to the city. Routledge.

11. Whitzman, C., Andrew, C., \& Viswanath, K. (2014). Partnerships for women's safety in the city:"Four legs for a good table". Environment and urbanization, 26(2), 443-456.

12. Cialdini, R. B., Reno, R. R., \& Kallgren, C. A. (1990). A focus theory of normative conduct: recycling the concept of norms to reduce littering in public places. Journal of personality and social psychology, 58(6), 1015.

13. Shaw, M., Andrew, C., Whitzman, C., Klodawsky, F., Viswanath, K., \& Legacy, C. (2013) Introduction: Challenges, opportunities and tools.

14. Tabibian, M., \& Shabanjoola, E. (2016). Comparison of pedestrian safety in old and new neighborhoods (A case study of Qazvin). Space Ontology International Journal, 5(1), 1-8.

15. Carmona, S., \& Ezzamel, M. (2016). Accounting and lived experience in the gendered workplace. Accounting, Organizations and Society, 49, 1-8.

16. Smith, M. J. (2008). Addressing the security needs of women passengers on public transport. Security Journal, 21(1-2), 117-133.

17. Loukaitou-Sideris, A., \& Fink, C. (2009). Addressing women's fear of victimization in transportation settings: A survey of US transit agencies. Urban affairs review, 44(4), 554-587.

18. Gehl, J. (2013). Cities for people. B.m.: Island press, 2013.

19. City planning and population health: a global challenge - ScienceDirect [online]. [vid. 2018-0804]. Dostupné

z: https://www.sciencedirect.com/science/article/pii /S0140673616300666

20. Assembly, U. G. (1979). Convention on the elimination of all forms of discrimination against women. Retrieved April, 20, 2006.

21. Adam, N. M., \& Schewe, P. A. (2007). A multilevel framework exploring domestic violence against immigrant Indian and Pakistani women in the United States. Journal of Muslim mental health, 2(1), 5-20.

22. Brady, M. (2005). Creating safe spaces and building social assets for young women in the developing world: A new role for sports. Women's Studies Quarterly, 33(1/2), 35-49.

23. Thynell, M. (2016). The quest for gender-sensitive and inclusive transport policies in growing Asian cities. Social Inclusion, 4(3), 72-82.

24. Sallis, J., Bauman, A., \& Pratt, M. (1998). Environmental and policy interventions to promote physical activity. American journal of preventive medicine, 15(4), 379-397.

25. Whyte, G. (1993). Escalating commitment in individual and group decision making: A prospect theory approach. Organizational behavior and human decision processes, 54(3), 430-455. 
26. Tandogan, O., \& Ilhan, B. S. (2016). Fear of crime in public spaces: From the view of women living in cities. Procedia engineering, 161, 2011-2018.

27. Tacoli, Cecilia a David Satterthwaite. (2013). Gender and urban change. B.m.: SAGE Publications Sage UK: London, England.

28. MOSER, Caroline, O. N. (2012). Gender planning and development: Theory, practice and training. B.m.: Routledge.

29. Beebeejaun, Y. (2017). Gender, urban space, and the right to everyday life. Journal of Urban Affairs, 39(3), 323-334.

30. Tembon, M. M., \& Fort, L. (Eds.). (2008). Girl's education in the 21st century: Gender equality, empowerment and growth. The World Bank.

31. Altman, I., \& Wohlwill, J. F. (2012). Human Behavior and Environment: Advances in Theory and Research Volume 2 (Vol. 2). Springer Science \& Business Media.

32. Bichard, J. A., \& Knight, G. (2012, September). Improving public services through open data: public toilets. In Proceedings of the Institution of Civil Engineers-Municipal Engineer (Vol. 165, No. 3, pp. 157-165). Thomas Telford Ltd.

33. Luymes, D. T., \& Tamminga, K. (1995). Integrating public safety and use into planning urban greenways. Landscape and urban planning, 33(1-3), 391-400.

34. Rana, I. A., \& Bhatti, S. S. (2018). Lahore, Pakistan-Urbanization challenges and opportunities. Cities, 72, 348-355.

35. Abbas, M. Z., \& Riaz, S. (2013). Legal Protections Provided Under Pakistani Law against AntiWomen Practices: Implementation Gaps between Theory and Practice. Dialogue (Pakistan), 8(2).

36. Weiss, A. M. (2012). Moving forward with the legal empowerment of women in Pakistan. US Institute of Peace.

37. Magdalena, M., \& Dananjojo, I. (2017). Pengaruh gender terhadap persepsi mengenai fasilitas jarak berjalan di lokasi penentuan titik simpul kereta api dan brt di bandar udara banjarbaru. Jurnal Transportasi Multimoda, 14(3), 121-128.

38. Noreen, N., \& Musarrat, R. (2013). Protection of women rights through legal reforms in Pakistan. Journal of Public Administration and Governance, 3(4), 119-142.

39. Altman. (2012). Irwin a Erwin H. ZUBE. Public places and spaces. B.m.: Springer Science \& Business Media.

40. Pritchard, A., Morgan, N. J., Sedgely, D., \& Jenkins, A. (1998). Reaching out to the gay tourist: opportunities and threats in an emerging market segment. Tourism management, 19(3), 273-282.

41. Raza, F. A. (2007). Reasons for the Lack of Women's Participation in Pakistan's Workforce. Journal of Middle East Women's Studies, 3(3), 99-102.
42. Jabeen, T., Sunbal, M., \& Taj, N. (2017). Relationship between Women Mobility and Sexual Harassment: Empirical Study of Metropolitan City of Lahore. Pakistan Journal of Criminology, 9(4), 90.

43. Michaud, A. (2006). Safety and coexistence: a gendered flow in urban space. URBANISM \& GENDER, 123.

44. Viswanath, K., \& Mehrotra, S. T. (2007). 'Shall We Go out?'Women's Safety in Public Spaces in Delhi. Economic and political weekly, 1542-1548.

45. Kamal, A., Malik, R. N., Martellini, T., \& Cincinelli, A. (2015). Source, profile, and carcinogenic risk assessment for cohorts occupationally exposed to dust-bound PAHs in Lahore and Rawalpindi cities (Punjab province, Pakistan). Environmental Science and Pollution Research, 22(14), 10580-10591.

46. Bhattacharya, S. (2014). Status of women in Pakistan. Journal of the Research Society of Pakistan, 51(1).

47. Kearl, H. (2010). Stop street harassment: Making public places safe and welcoming for women. ABC-CLIO.

48. Stanko, E. A. (1993). The case of fearful women: Gender, personal safety and fear of crime. Women \& Criminal Justice, 4(1), 117-135.

49. Jalal, A. (1991). The convenience of subservience: Women and the state of Pakistan. In Women, Islam and the state (pp. 77-114). Palgrave Macmillan, London.

50. Mehdi, R. (2010). The Protection of Women (Criminal Laws Amendment) Act, 2006 in Pakistan. Droit et cultures. Revue internationale interdisciplinaire, (59), 191-206.

51. Mishra, S. A., \& Pandit, R. K. (2013). Urban transformation and role of architecture towards social sustainability. Int J Eng Res Dev, 5, 16-20.

52. Khan, A., \& Hussain, R. (2008). Violence against women in Pakistan: Perceptions and experiences of domestic violence. Asian Studies Review, 32(2), 239-253.

53. Franck, K. A., \& Paxson, L. (1989). Women and urban public space. In Public places and spaces (pp. 121-146). Springer, Boston, MA.

54. Madhani, F. I., Karmaliani, R., Patel, C., Bann, C. M., McClure, E. M., Pasha, O., \& Goldenberg, R. L. (2017). Women's perceptions and experiences of domestic violence: An observational study from Hyderabad, Pakistan. Journal of interpersonal violence, 32(1), 76-100.

55. Thynell, M., Mohan, D., \& Tiwari, G. (2010). Sustainable transport and the modernisation of urban transport in Delhi and Stockholm. Cities, 27(6), 421-429.

56. Fainstein, S. S. (2005). Planning theory and the city. Journal of planning education and research, 25(2), 121-130. 